\section{Relevance of the application of institutional theory in Shariah governance of Islamic banks}

\section{Application of institutional theory}

\author{
Yusuf Karbhari
}

Department of Accounting and Finance, Cardiff Business School, Cardiff University, Cardiff, UK

Md. Kausar Alam

Department of Accounting and Finance, Faculty of Economics and Management, Universiti Putra Malaysia, Serdang, Malaysia, and

\author{
Md. Mizanur Rahman \\ Department of Business Administration, \\ Metropolitan University Sylhet, Sylhet, Bangladesh
}

Received 18 May 2020 Revised 13 August 2020 Accepted 19 September 2020

\begin{abstract}
Purpose - Prior studies on Islamic finance provide a limited linkage between organizational theory and the complex Shariah governance framework embraced by Islamic banks worldwide. This paper aims to show the relevance of the application of "institutional theory" in the Shariah governance framework of Islamic banks.

Design/methodology/approach - This study applied library research to investigate the application of institutional theory in the Shariah governance framework of Islamic banks. The authors also critically reviewed prior empirical and review papers for accomplishing the research objectives.

Findings - Based on the critical review, the authors found that institutional theory is the most influential in progressing Shariah governance as it contributes toward the organizational image, helps to achieve religious legitimacy, and inspires a more robust regulatory environment. In addition, a well-designed Shariah governance framework is driven by institutional theory and that could assist in providing guidelines, strategies and procedures for Islamic banks to better conduct; monitor and control their social, religious and accountability obligations. The authors also highlighted the societal, economic and legal environment of Islamic banks in relation to the propositions of institutional theory. They emphasize that a well-designed Shariah governance framework driven by institutional theory could assist in providing guidelines, strategies and procedures for Islamic banks to better conduct, monitor and control their social, religious and accountability obligations.
\end{abstract}

Research limitations/implications - This study highlights institutional theory to serve best the development of operational strategies and structures of Islamic banks including the roles, functions and powers of the various stakeholders including regulators and those involved in the Shariah governance

(C) Yusuf Karbhari, Md. Kausar Alam and Md. Mizanur Rahman. Published in PSU Research Review. Published by Emerald Publishing Limited. This article is published under the Creative Commons Attribution (CC BY 4.0) licence. Anyone may reproduce, distribute, translate and create derivative works of this article (for both commercial and non-commercial purposes), subject to full attribution to the original publication and authors. The full terms of this licence may be seen at http:// creativecommons.org/licences/by/4.0/legalcode

The authors would like to thanks the Editor-in-Chief and anonymous reviewers for their valuable comments and suggestion for the improvement of this manuscript. The authors do not receive any specific research fund for conducting this research. 
PRR

5,1

process of Islamic banks. The authors recognize the institutional theory to perform a key role in enriching the structural framework of Islamic Financial Institutions. This study is heavily dependent on prior research rather than empirical investigations. The authors did not cover other Islamic finance areas (such as Islamic insurance, Islamic microfinance and Halal industries). Thus, future researchers can apply institutional theory in Shariah governance practices and implementations of setting up rules by the regulators and respective institutions.

Originality/value - To the best of the authors' knowledge, this is the first study that attempts to show the importance of the application of institutional theory in Shariah governance of Islamic Banks. Thus, this study, therefore, adding a novel dimension to the literature by arguing why institutional theory, is more pronounced (as compared to the other theoretical frameworks) in the formation and discharge of the roles, powers and functions by the different governance organs (such as regulators, the board of directors, management and Shariah supervisory board) operating in this unique corporate governance landscape.

Keywords Islamic banks, Institutional theory, Shariah governance framework

Paper type Literature review

\section{Introduction}

Seeing the global popularity of Islamic finance in Muslim jurisdictions over the past few decades, it is plausible to suggest that Islamic organization's governance processes and structures are more complex than the conventional corporate governance systems. From the previous studies, it is found that Shariah governance is a vital component of the overall corporate governance structure of the Islamic banking industry, but it has been received little attention in prior literature (Yoshikawa et al., 2007; Chakrabarty and Bass, 2014; Morrison, 2014). Crucially, without effective governance mechanisms in place, Islamic Banks cannot deliver the religious and ethical legitimacy that usually the stakeholders require. For this reason, the Accounting and Auditing Organization for Islamic Financial Institution (AAOIFI) and International Financial Services Board (IFSB) explicitly outlined a framework for Shariah governance framework requiring Islamic banks to implement appropriate structures and processes to ensure that their operations are in absolute conformity with religious beliefs (Iqbal and Mirakhor, 2004; Grais and Pellegrini, 2006a; Kamla and Alsoufi, 2015; Ullah et al., 2016; Karbhari et al., 2018; Alam et al., 2020a).

Intuitively, an effective Shariah governance framework for Islamic banks should comprise robust structural governance arrangements that would enable Islamic banks to safeguard oversight and responsibility of the board of directors, its management and particularly, their Shariah supervisory boards [1]. Abu-Tapanjeh (2009) claimed that any process that avoids a suitable ethical and moral structure would most probably default to generate a complete Islamic governance system. Unlike the Western approach, Islamic teachings on business integrate both spiritual and temporal issues (Archer and Karim, 2007; Karim, 1995; Karim, 2001; Tinker, 2004), and relatively little is known about them especially in terms of their epistemological positioning [2]. Furthermore, in an Islamic context, Kamla (2009) rightly asserts that if Islam is purely practiced and without unnecessary laxity, it will accomplish its described socio-economic ambitions. However, when examining religion's influence on business, raises some important questions because contemporary business systems have their roots firmly entrenched in the Western Enlightenment movement and positivist thought, with the "secular" being separated from the "sacred" and the "normative" discarded from the "discourse" (Gambling and Karim, 1991; Hamid et al., 1993; Tinker, 2004; Carmona and Ezzamel, 2006).

Although a plethora of studies exists relating to Islamic finance, there is negligible prior research that explicitly examines religious governance from a theoretical standpoint. Explaining Shariah governance concerning managerial frameworks, three theories, namely, 
agency theory (Jensen and Meckling, 1976), stewardship theory (Donaldson and Davis, 1991) and stakeholder theory (Freeman, 1984), have generally been espoused in prior literature (Obid and Naysary, 2014; Al-Nasser Mohammed and Muhammed, 2017). However, when examining these competing theories, Obid and Naysary (2014) highlighted some limited ideas had been highlighted connected with Shariah governance which includes issues on accountability, independence, transparency, disclosure, competence and confidentiality. However, the above studies also do not focus on discussing the theoretical development of the religious institutions' formation, and organizational Shariah governance structure, system and control. All of the theories discuss the ownership control, interest of the managers and benefit of the other parties, but it is unexpected that none of the theory outlines the roles, functions and powers of agent, stewards and stakeholders and other related parties highlighting accountability, independence, competence, confidentiality and transparency and disclosure by outlining the Shariah governance structure, procedures and rules (Hassan, 2012). In this regard, to overcome this limitation, the institutional theory has been adopted in this study, where this theory describes the operational guidelines and procedures for the organization. By outlining the roles and powers of the various stakeholders along with the regulators, institutions, centralized Shariah supervisory board, the board of directors, Shariah supervisory board, management and Shariah officers, the institutional theory acts as an important role in the enhancement of organizational structure and performance by balancing the stakeholders' roles.

Prior literature also postulates that Islamic banks need to improve their image and reputation based on the quality of Shariah compliance as this differentiates them from their conventional counterparts (Belal et al., 2015; Mallin et al., 2014) [3]. However, as the concepts and principles prescribed by Islamic faith differ markedly from the systems adopted in traditional corporate governance, there are widespread normative (Islamic spiritual philosophies and values) and critical reviews about the uniqueness of Islamic governance frameworks (Kamla et al., 2006; Choudhury and Hoque, 2006; Abu-Tapanjeh, 2009; Williams and Zinkin, 2010). For example, conventional corporate governance emphasizes profitmaking and institutional performance, whereas Shariah governance focuses purely on the implementation of Islamic principles in applying a Shariah governance framework. Moreover, Carpenter and Feroz (2001) claimed that effective institutions are those that attain legitimacy in the social order by following pressures and resorting to legitimization strategies to validate societal and financial suitability.

DiMaggio (1998) focusing on institutional theory and its influence on religious institutions, asserted that institutional theory is relevant to the goals of religious institutions, while conventional business institutions have additional tendency to consider coherent actors and an image centering on the maximization of profit. In this context, prior studies on institutional theory have emphasized corporate governance (Yoshikawa et al., 2007; Chakrabarty and Bass, 2014; Morrison, 2014), and on the corporate community development practices of Islamic banks in Bangladesh. Whereas the prevailing theories of Shariah governance disclose the entwined relationship between Shariah governance and regulation, institutional theory helps to unveil the missing link in the way that Islamic banks impact regulation in society [4]. The theory helps deliver a structure for recognizing how existing practices and standards amongst similar organizations influence the way that regulation (i.e. in this case, Shariah governance) is both interpreted and implemented in Islamic banks [5].

We are motivated to consider institutional theory as the leading theory as it best illuminates the operational guidelines and procedures for Islamic financial institutions. Our reasoning is based on the fact that institutional theory elucidates on the roles and

Application of institutional theory 
PRR

5,1

responsibilities of diverse stakeholders (such as regulators, institutions and Shariah supervisory boards) operating in an Islamic governance mosaic and highlights how it contributes to enhancing organizational structures. Second, the institutional theory provides a more suitable basis when considering a Shariah governance framework for Islamic banks because of its capacity to deal with operational guidelines and procedures for organizations. Third, institutional theory advocates that organizations implement structures, systems and processes which are regarded as legitimate in culture for their existence. Therefore, Islamic banks are also affected by the coercive, normative and mimetic pressures in relation to their unique organizational setting and implement the "acquiesce," "compromise," "avoid," "defy" and "manipulate" tactics to reply to pressures. Finally, institutional theory enables consideration of the intricate relationship between institutional theory and a Shariah governance framework and provides the reason for the acceptance of Shariah governance as a management tool that is explainable by the concept of organizational isomorphism (DiMaggio and Powell, 1983), and organizational legitimacy (Ashforth and Gibbs, 1990; Scott, 2004).

To our knowledge, this is the first study that attempts to show the importance of the application of institutional theory in Shariah governance of Islamic Banks. Thus, this study, therefore, adds a novel dimension to the literature. First, we contribute to prior literature on Shariah governance as it provides valuable insight on why institutional theory is more pronounced (as compared to the other theoretical frameworks) in the formation and discharge of the roles, powers, and functions by the different governance organs (such as regulators, the board of directors, management and Shariah supervisory boards) operating in this unique corporate governance landscape. Second, by highlighting that the structures, procedures and rules of Shariah governance is better represented by institutional theory and is, therefore, more relevant in ensuring accountability, independence, competence, confidentiality and transparency and disclosure resulting in improved quality Shariah governance. We justified that institutional theory is more relevant in the application of Shariah governance and why the regulators and industry should more focus on this theory in developing and executing the Shariah governance of Islamic banks. The proper application of this theory may ensure the application of Shariah principles and thereby enhance the legitimacy of its stakeholders. Third, we highlight that by practicing the structures, procedures and rules of Shariah governance, the numerous institutional structures help to attain a mutual goal such as to stimulate sound Shariah governance practices and applying them in practice. Fourth, by focusing on the issue of isomorphism, our study allows a more profound understanding to be gained on the shaping of internal structures and actions of Islamic financial institutions. This could contribute toward improving the overall image of Islamic banks, as it allows the proper application of Shariah rules thus helping to achieve organizational legitimacy and improving Shariah compliance quality critical for Islamic banks and their stakeholders.

The remainder of this paper is as follows. Section 2 provides a discussion of our critical review of the literature on the theoretical frameworks and evaluates these in the context of Islamic banks and a Shariah governance framework. Section 3 deliberates on the contribution of institutional theory toward the development of Islamic banks, and finally, Section 4 concludes the study.

\section{Application of institutional theory on Shariah governance framework}

The meaning of institutional theory is a statement on the more in-depth and more flexible characteristic of societal structure (Scott, 1987). It deliberates on the process by structures containing application, regulative, normative and cultural cognitive, which is recognized as 
commanding strategies for societal behavior. Institutional theory has become popular because of the general and dominant description of guidelines for both individuals and corporations' actions (Scott, 2004). In addition, Meyer and Rowan (1977) and Zucker (1977) drew a novel tactic of an institutional predictor that emphasizes the social character and perception in the institutional inquiry. Meyer and Rowan (1977) highlighted that organizational guidelines work as mythologies through institutions that incorporate acquisition legitimacy, constancy and improved survival prospects. This suggests that rational ideas of corporations are the key power for institutions to adjust applications and processes to improve their legitimacy and existence (Meyer and Rowan, 1977).

In 1983, DiMaggio and Powell elaborated on the work of Meyer and Rowan (1977) on isomorphism to the organizational field level (micro-level) and from the social level (macrolevel). They outlined three isomorphic procedures such as "coercive" to attain legitimacy, "mimetic" to eliminate uncertainty and "normative" mainly from professionalization. New institutionalism is a clarification for the achievement and existence of institutions (DiMaggio and Powell, 1983). Interestingly, Tolbert and Zucker (1983) rejected rationality and highlighted legitimacy instead of competency. Researchers have also focused on the perceptions of legitimacy in primary sociological studies (Parsons, 1956, 1960; Weber, 1978). Illustrating their work, researchers in the arena tend to work in two different aspects of legitimacy (Suchman, 1995). First, the strategic approach (Pfeffer, 1981; Ashforth and Gibbs, 1990) and second, the institutional approach (DiMaggio and Powell, 1983; Zucker, 1987; Meyer and Rowan, 1991). In this tactic, organizations have a tendency to seek legitimacy over obeying rules and regulations that are developed by the cultures and the organization's internal structures. Organizational isomorphism is the main component of institutional theory in which institutions implement similar processes through coercive, mimetic, and normative isomorphism's as outlined in the earlier work (DiMaggio and Powell, 1983). Consequently, Greenwood and Hinings (1996) stated that the institutional theory tactic describes the similarities and the modification in organizational structure rather than focusing on discovering its changes. Scott (2004) showed that to persist; institutions must follow guidelines and the belief structures dominant in the setting (Meyer and Rowan, 1977; DiMaggio and Powell, 1983) because organizational isomorphism both the structural and procedural will achieve organizational legitimacy (Dacin et al., 2002; Suchman, 1995; Deephouse, 1996).

Due to the absence of a control instrument or governance procedure, the confidence of the general public toward the Islamic banks' legitimacy and validity of the products may be decreased (Chapra and Ahmed, 2002). In this regard, the Shariah supervisory board is considered crucial to the Shariah governance framework of Islamic banks. The role of the Shariah supervisory board is to independently monitor the overall Islamic banking activities concerning the Shariah rules and regulations. Consequently, from the stakeholder perspective, Shariah governance plays a role similar to corporate governance that is also used to estimate the compliance of the overall activities to confirm the Shariah principles are upheld. Shariah governance is directed by a complete set of Shariah governance framework which provides a comprehensive structure of roles and responsibilities for all the related parties (management establishment and affairs of the Shariah supervisory board) with the Shariah compliance guidelines of Islamic banking practices concerning the Shariah rules (Alam et al., 2020b). However, in protecting the rights of stakeholders and as a control mechanism of Shariah governance, managers have to perform a vital role in implementing Shariah rules and monitoring the banking activities. In Islamic financial institutions, managers must be accountable to God in parallel to shareholders and the company with the final objective of well-being and accomplishment for humanity (Abu-Tapanjeh, 2009) which

Application of institutional theory 


\section{PRR}

5,1

is a default idea from the self-interest concept prescribed in agency theory. Consequently, the aim of the particular observing process of Shariah governance is to confirm compliance among Islamic banks concerning the ideologies of Shariah and to prepare a Shariah report which may play a significant role toward owners, other stakeholders (Grais and Pellegrini, 2006a). An organization is not only involved in the structures, procedures and processes for a particular institution but also for numerous institutional structures practicing together to attain a mutual goal such as to stimulate a sound Shariah governance practices and applying them in their practice.

However, institutional theory refers to the ability of the countries and institutions to implement alike (Shariah governance) structures and exercises as isomorphism (DiMaggio and Powell, 1983). Carpenter and Feroz (2001) describe this procedure as organizational marking, and they claim that this procedure does not necessarily make institutions more effective. Further, Carruthers (1995) argues that the institutional process is a social and political issue that denotes legitimacy and authority much more than effectiveness alone. Thus, the countries and institutions can implement particular Shariah governance exercises not only for the enhancement of performance or drive to financial development but also to attain legitimacy in culture (Alam et al., 2020c). In the present societies, legitimacy is given to the political organizations that provide based on society's cultural rules and beliefs (Covaleski and Dirsmith, 1988). Besides, Deegan (2002) suggests that if society's prospects concerning the legitimacy of a government or institution are not changed, then their "agreements" for presence are efficiently withdrawn by culture. Moreover, only the effectiveness is not the sole way to survive but attaining legitimacy and faith is a new most significant survival approach.

Institutional theory delivers a beneficial structure for realizing the social, financial and legal effects on the countries and institutions and their tactical replies to those effects (Covaleski and Dirsmith, 1988; Carruthers, 1995; Brignall and Modell, 2000). It also suggests that the components of proper structures, strategies and processes were generally generated from the mythologies relating to suitable social and economic customs (DiMaggio and Powell, 1983). In this case, the Shariah governance framework also provides the overall guidelines, strategies and procedures for Islamic banks to conduct, monitor and control their activities. Mythologies are general beliefs about mostly acknowledged rules and which have become intensely rooted in culture and have attained legitimacy (Meyer and Rowan, 1977).

From a Shariah governance perspective, Bhatti and Bhatti (2010) observed that the corporate governance which is authorized by the religious would inspire the capital development, substitute robust markets, generate incentives to participate in valuemaximizing behavior and motivate decision and clearness. Abu-Tapanjeh (2009) also highlighted that the absence of a proper ethical system would most probably fail to generate an appropriate structure of governance. Therefore, it appears that Islamic institutions can influence the enhancement of Shariah governance practice in a proper way. Another component of Shariah governance is the diversification from the Western idea which denotes its epistemological orientation. Agreeing with the compliance of a corporate governance structure, registered corporations in Islamic countries continuously have the option to obey with Shariah constructed regulation in overall legal and monetary functions, and it is non-compulsory as it is harmonious with the code of corporate governance and does not deny it. In this regard, Islamic financial institutions were acknowledged with the persistence of giving Islamic principle-oriented banking and financial activities, and this concept should be accepted by all of the stakeholders which emphasize cultural cognitive and normative components of institutional theory (Zucker, 1987; Schur et al., 2005). In the context of Shariah principles, the Shariah governance structure of Islamic banks is modestly unique 
because that should obey a distinct set of rules based on the Holy Quran and the Sunnah, which contains the ideologies of social fairness and accountability (Khan and Bhatti, 2008). In this case, it generates a soft power relation concerning the macro (Institutional) and micro (distinct) levels (Zucker, 1987). It is also affected by normative pressures, sometimes ascending from the internal and outsider source, i.e. board of directors, Shariah supervisory board, regulatory authorities and the state. These normative pressures stimulate the implementation of an organization's procedures which are controlled by the top management in their judgments (Farrington and Farrington, 2005; Tsai et al., 2013).

Shariah governance structure ensures justice among the stakeholders to be touched over the improvement of transparency and responsibility (Alam et al., 2020d; Majeed, Aziz and Saleem, 2015) by stimulating Islamic principles, i.e. justice, Shariah compliance, zakah management (Mittal, Sinha, and Singh, 2008). Moreover, the Shariah governance structure describes the boards association, formation of various committees along with their members, management and exchange of information amongst them (Zahra and Pearce, 1989). Institutional theory endeavors to outline more essential features of how institutions are shaped, continued, altered and postponed, and contracts with the pressures of Islamic financial institutions on human behavior comprising their practices, i.e. guidelines, practices and standards way social behavior. Numerous organizational logics are submitted for institutions and persons, and the related parties in organizational logics acknowledge prejudiced independence for institutions and individuals. Moreover, the accomplishments, valuation and results are an outcome of associations between individuals and institutional arrangements. The institutional theory involves an analysis of how few of the institutions' social systems comprising outlines, rules, standards and procedures, become recognized as commanding strategies for institutional behavior (Scott, 2004). In this regard, Islamic banks adopt Shariah principles for controlling their business activities.

Meanwhile, resource inadequacy, stimulates corporate boards to involve in interorganizational connections in an endeavor to adequate influences of exterior pressures upon their corporations (Pfeffer and Salancik, 1978). Together with the board of directors and management, the Shariah supervisory board is an internal autonomous authority. As an inner mechanism of Shariah governance of Islamic bank, therefore, improving the trustworthiness of the corporations' in the view of shareholders, stakeholders, i.e. depositors, investors and customers and strengthening their Islamic identifications, and they rely on the Shariah supervisory board (Rammal, 2006; Greuning and Iqbal, 2008). Fundamentally, the Shariah supervisory board assures that Islamic banks are conducting their operational functions in accordance with Shariah (Alam et al., 2020e). Mostly, the Shariah supervisory board works with management to ensure whether the commercial products or services provided obey the guidelines stipulated by Islamic law. An additional role for the Shariah supervisory board is to confirm the transparency and accountability in the Shariah process (Majeed et al., 2015) and to assure that all functions of the Islamic bank comply with Shariah principles and ethics (Alam et al., 2019a; Grassa, 2016). In short, the Shariah supervisory board is associated with the inner governance structure of the organization and performs as an in-house monitoring authority within the institution. However, the failure to confirm the Shariah principles might expose the Islamic financial institutions to reputational risk toward the institution individually and the overall industry (Grais and Pellegrini, 2006b).

\section{Impact of institutional theory on Islamic banks}

Early institutional theory researchers in political science emphasized the managerial schedules and legal structures that form governance frameworks (Wilson, 1889;

\section{Application of institutional theory}

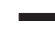


PRR

5,1

Willoughby, 1896; Burgess, 1902). It was DiMaggio (1998) who expanded institutional theory discourse to religious institutions by concentrating on the concepts of the "procedural," "figurative understanding" and "cultural legitimacy." Besides, he claimed that institutional theory is relevant and equivalent to the goals of Islamic institutions while conventional business institutions tend to focus more on coherent factors and an image centering on the maximization of profit [6]. In this context, Islamic banks "corporate image" might be described from twice perspectives such as performative image and institutional image based on institutional theory (Handelman and Arnold, 1999). The image of Islamic banks can comprise being Islamic, modest, fair, constant and clear (institutional image), along with being friendly, truthful, pleasing, leading, trustworthy and protected (performative images). In this case, the authors also found that institutional image is the central concern in Islamic banks and conduct their banking affairs based on Shariah principles and how the Shariah is the main motive for Muslims to select Islamic banks. Moreover, Yeo and Youssef (2010) examined the corporate image of Saudi Arabian Islamic banks over corporate management, corporate communication and financial prospects. Furthermore, the name of the banks, image, privacy, friends as well as family inspiration and arrangement of quality services [7] are similarly significant to the customers in their decision-making process to choose a bank (Mettawa and AlMossawi, 1998). Therefore, research, based on the Islamic banks' service quality in Malaysia, stated that the compliance measurement was the most important measurement among the customers of Islamic banks (Parasuraman et al., 1985). After all, Islamic banking is an area that has been acknowledged to provide banking services according to Islamic Shariah and related to protecting the rights of all stakeholders (Alam et al., 2019b). In addition, Delener (1994) suggested that religiosity would influence the individual's behavior and decision-making process. This is called one kind of institutional culture which emphasizes cultural-cognitive and normative components of institutional theory (Zucker, 1987; Schur et al., 2005).

Nevertheless, though the corporations are compelling with nature such as practices or environment or diversification of organizational behaviors or organizational strategies, they can reply toward the institutional pressures in a diversified way (Oliver, 1991, 1997; Greenwood and Hinings, 1996; Roberts and Greenwood, 1997). In addition, Oliver (1991) posits that institutions reply to organizational pressures that influence them by applying "acquiesce," "compromise," "avoid," "defy" and "manipulate" approaches. The "acquiesce" approach suggests that institutions receive and obey organizational pressures by altering their particular structures and processes to implement broadly acknowledged practices and processes. In this case, Islamic banks follow the country's rules and regulations or follow the superior organizations' strategies in this industry. The "compromise" approach states to balance the contradictory prospects of the numerous institutions and parties over the legislative bargaining procedure (Khadaroo and Shaikh, 2007). Alternatively, institutions might "avoid" the obligation to ensure to organizational pressures by covering their Shariah non-performance or over altering their functions. Few institutions at their individual risk might "defy" guidelines and adequate standards and practices by discharging, stimulating or arguing them. Still, another can make an effort to "manipulate" rules and norms by trying to impact and regulate them. In sum, the institutional theory suggests that institutions implement structures, systems and processes which are apparent as legitimate in culture to enhance their probabilities of existence. They are related to different pressures (coercive, normative and mimetic) in their organizational settings and continually employ diverse approaches ("acquiesce," "compromise," "avoid," "defy" and "manipulate”) to reply to these pressures. 


\section{Conclusion}

This study examines the relevance and applicability of the institutional theory in formulating a Shariah governance framework for Islamic banks. Although prior research provides guidance on the rights, powers, ownership, control and the interest of managers, owners, shareholders, stewards and other related parties, nevertheless, deficiencies remain. This study highlights institutional theory to serve best the development of operational strategies and structures of Islamic banks including the role, function and power of the various stakeholders including regulators and those involved in the Shariah governance process of Islamic banks. We recognize the institutional theory to perform a key role in enriching the structural framework of Islamic financial institutions.

At the heart of discourse is whether institutional theory provides the necessary processes by which structures, comprising rules, norms and practices, become developed and authorized as satisfactory corporate practice. For these reasons, this study delineates two complementary mechanisms of institutional theory concerning a Shariah governance framework and how this can be implemented. First, the issue of isomorphism, where organizations desire to implement homogeneous structures, policies and processes to other organizations in their environment (DiMaggio and Powell, 1983). Finally, legitimacy where an organization's persistence needs it to follow with social rules of adequate behavior, ascending from the grade deliberated by outdoor concerned parties, generally the government, the general people or the professions (Meyer and Rowan, 1977; Deephouse, 1996; Covaleski and Dirsmith, 1988).

Overall, from an institutional theory lens, Shariah governance is a holistic overview of relationships to various parties related to Islamic banks. Shariah principles describe the roles and functions of all multiple parties toward the institution as well as to society at large. The overall outlook of Shariah governance indicates that wider institutional structures surround the governance system. This posits that the Shariah governance structure should be more comprehensive and socially developed than the general association of the agent principle outlook to protect the interest of all parties. As researchers, in recent years, have paid attention to institutional theory to illuminate variations in institutional multiplicity (Morphew, 2009; Morphew and Huisman, 2002), the theory does, nevertheless, have several limitations. For instance, institutional theory recommends a "presumed unidirectional coercive effect of laws and regulations" (Morphew and Huisman, 2002) that may enhance or decline institutional multiplicity. Researchers such as Oliver (1988) rightly note that institutional theory adequately elucidated isomorphism within organizational arenas and that organizations may have a better opportunity in shaping their internal structures and actions whereas other features of institutions may show more or less resilience to these pressures. For these reasons, we have argued how institutional theory is the more relevant in advancing the cause of implementing an effective Shariah governance framework as it better contributes to improving the overall image of Islamic banks as well as it enables the proper application of Shariah rules which can help increase the quality of Shariah compliance not only for the benefit of Islamic banks but also, more importantly, for their stakeholders. In the meantime, based on the evidence provided in this study, we propose that a rounded acknowledgment of institutional theory be driven through the Islamic banking industry that to initiate a fresh outlook toward Shariah governance.

This study is heavily dependent on prior research rather than empirical investigations. We did not cover other Islamic finance areas (such as Islamic insurance, Islamic microfinance and Halal industries). Thus, future researchers can apply institutional theory in Shariah governance practices and implementations of setting up 
rules by the regulators and respective institutions. Future studies can apply institutional theory in the area of institutional development and Shariah governance practices of Islamic insurance, Islamic microfinance and Islamic social finance. Researchers can apply institutional theory in the areas mentioned above by using a quantitative and qualitative methodology through regulatory policies, guidelines and regulations. Finally, the application of institutional theory would enhance in Islamic finance areas.

\section{Notes}

1. A Shariah Supervisory Board is defined as "an independent body entrusted with the duty of directing, reviewing, and supervising the activities of Islamic Banks for the purpose of Shariah compliance and issuing legal rulings relating to Islamic banking and finance” (AAOIFI, 2005). The IFSB has also defined a Shariah supervisory board as "a body comprised of a panel of Shariah scholars who provide Shariah expertise and who act as special advisers to the institutions" (IFSB, 2009).

2. From a Western perspective, the main difference between $C G$ and the religiously driven Shariah governance is its epistemological orientation (Choudhury and Alam, 2013; Nathan and Ribieri, 2007; Grassa, 2013; Platonova et al., 2016). Uniquely to Islam, Muslims and Islamic organizations are accountable to God and are required to comply with a strict ethical code. Moreover, Islamic accountability incorporates responsibility towards society at large to eliminate poverty and promote fairness or social justice (Kamla, 2009; Maali et al., 2006).

3. The general aim of an Islamic bank is to provide banking services based on the rules prescribed by the Islamic faith. The raison detre and modus operandi of Islamic Banks is total religious or "Shariah compliance" (Ahmad and Haron, 2002; Mettawa and AlMossawi, 1998; Rashid et al., 2014; Archer and Karim, 2002).

4. Kalbers and Fogarty (1998) claim that "organizational structures have become symbolic displays of conformity and social accountability". In the context of this study, several governance accomplishments and structures are driven in Islamic Banks to fulfill legitimacy and accountability through the intricate role played by Shariah supervisory board ss as part of the overall governance framework.

5. Institutional theory highlights the structure and arrangement of an institution's setting, proposing that the suitable structure of organization's is not simply a combination of resource dependencies and mechanical demands, but is inclined by structural arrangements, containing rational mythologies, perceived knowledge legitimized over the enlightened structure and by the occupations, community belief and regulation (Meyer and Rowan, 1977; Zucker, 1977; DiMaggio and Powell, 1983; Scott, 1987). Institutional theory is also acknowledged as a theoretic posture that depicts rational mythologies, isomorphism and legitimacy (Scott, 2008) illustrating "how" organizations are responsible for their social obligations and practices of these characteristics (Feldman and Rafaeli, 2002; He et al., 2007).

6. The bank has three substitutes of becoming purely Islamic or remaining as conventional or partially operating Islamic banking through Islamic windows. Definitely, the most suitable is to be fully Islamic, but most of the Islamic banks have chosen for the third position and opt for stability instead thereby becoming isomorphic to the counterpart banks. (Abdul-Baki and Uthman, 2017).

7. Service quality is the key element which motivates individuals to support Islamic banks (Haque et al., 2009). Conversely, Islamic banks customers have increased satisfaction levels from the view of Islamic banks products, services and facilities in numerous countries. Also, customers of Islamic banks are conscious of the different products, i.e. mudarabah, musharakah and murabaha (Okumuş and Genc, 2013). 


\section{References}

AAOIFI (2005), "Governance Standards for IFIs", No. 1-5, AAOIFI, Accounting andAuditing Organization for Islamic Financial Institution, Bahrain, available at: http://aaoifi.com/standard/ accounting-standards/lang=en

Abdul-Baki, Z. and Uthman, A.B. (2017), "Exploring the 'social failures' of Islamic banks: a historical dialectics analysis", Journal of Islamic Accounting and Business Research, Vol. 8 No. 3, pp. 250-271.

Abu-Tapanjeh, A.M. (2009), "Corporate governance from the Islamic perspective: a comparative analysis with OECD principles", Critical Perspectives on Accounting, Vol. 20 No. 5, pp. 556-567.

Ahmad, N. and Haron, S. (2002), "Perceptions of Malaysian corporate customers towards Islamic banking products and services", International Journal of Islamic Financial Services, Vol. 3 No. 4, pp. 1-16.

Al-Nasser Mohammed, S.A.S. and Muhammed, J. (2017), "The relationship between agency theory, stakeholder theory and Shariah supervisory board in Islamic banking: an attempt towards discussion”, Humanomics, Vol. 33 No. 1, pp. 75-83.

Alam, M.K., Ahmad, A.U.F. and Muneeza, A. (2020c), "External Sharīah audit and review committee vis-a-Vis Sharīah compliance quality and accountability: a case of Islamic banks in Bangladesh", Journal of Public Affairs, doi: 10.1002/pa.2364.

Alam, M.K., Miah, M.S., Siddiquii, N. and Hossain, M.I. (2020a), "The influences of board of directors and management in Shariah governance guidelines of the Islamic banks in Bangladesh", Journal of Islamic Accounting and Business Research, Vol. 11 No. 9, doi: 10.1108/JIABR-08-2019-0155.

Alam, M.K., Rahman, S.A., Mustafa, H., Shah, S.M. and Hossain, M.S. (2019a), "Sharīah governance framework of Islamic banks in Bangladesh: practices, problems and recommendations", Asian Economic and Financial Review, Vol. 9 No. 1, pp. 118-132.

Alam, M.K., Rahman, S.A., Mustafa, H., Shah, S.M. and Rahman, M.M. (2019b), “An overview of corporate governance models in financial institutions", International Journal of Management and Sustainability, Vol. 8 No. 4, pp. 181-195, doi: 10.18488/journal.11.2019.84.181.195.

Alam, M.K., Rahman, S.A., Thakur, O.A., Bashir, M.A. and Hosen, S. (2020e), "The reasons behind the absence of a comprehensive Shariah governance framework for the Islamic banks in Bangladesh", International Journal of Economics and Business Administration, Vol. 8 No. 1, pp. 134-145.

Alam, M.K., Mustafa, H., Uddin, M.S., Islam, M.J., Mohua, M.J. and Hassan, M.F. (2020b), "Problems of Shariah governance framework and its mechanisms: an empirical investigation of Islamic banks in Bangladesh", The Journal of Asian Finance, Economics and Business, Vol. 7 No. 3, pp. 265-276.

Alam, M.K., Tabash, M.I., Thakur, O.A., Sahabuddin, M., Hosen, S. and Hassan, M.F. (2020d), "A Central Shariah regulatory authority for the Islamic banks in Bangladesh: Legalization or formation”, The Journal of Asian Finance, Economics and Business, Vol. 7 No. 1, pp. 91-100.

Archer, S. and Karim, R.A.A. (2002), "Islamic Finance Innovation and Growth, Euro-money Books and AAOIFI", London.

Archer, S. and Karim, R.A. (2007), Islamic Finance: The Regulatory Challenge, John Wiley and Sons (Asia).

Ashforth, B.E. and Gibbs, B.W. (1990), "The double-edge of organizational legitimation", Organization Science, Vol. 1 No. 2, pp. 177-194.

Belal, A.R., Abdelsalam, O. and Nizamee, S.S. (2015), "Ethical reporting in Islamic bank Bangladesh limited (1983-2010)", Journal of Business Ethics, Vol. 129 No. 4, pp. 769-784.

Bhatti, M. and Bhatti, M.I. (2010), "Toward understanding Islamic corporate governance issues in Islamic finance", Asian Politics and Policy, Vol. 2 No. 1, pp. 25-38.

Brignall, S. and Modell, S. (2000), "An institutional perspective on performance measurement and management in the "new public sector", Management Accounting Research, Vol. 11 No. 3, pp. 281-306. 
PRR

5,1

Burgess, J. (1902), Political Science and Comparative Constitutional Law, Ginn, Boston.

Carmona, S. and Ezzamel, M. (2006), "Accounting and religion: a historical perspective”, Accounting History, Vol. 11 No. 2, pp. 117-127.

Carpenter, V.L. and Feroz, E.H. (2001), "Institutional theory and accounting rule choice: analysis of four US state governments' decisions to adopt generally accepted accounting principles", Accounting, Organizations and Society, Vol. 26 Nos 7/8, pp. 565-596.

Carruthers, B.G. (1995), "Accounting, ambiguity, and the new institutionalism", Accounting, Organizations and Society, Vol. 20 No. 4, pp. 313-328.

Chakrabarty, S. and Bass, A.E. (2014), "Corporate governance in microfinance institutions: board composition and the ability to face institutional voids", Corporate Governance: An International Review, Vol. 22 No. 5, pp. 367-386.

Chapra, M.U. and Ahmed, H. (2002), Corporate Governance in Islamic Financial Institutions, Islamic Development Bank: Islamic Research and Training Institute.

Choudhury, M.A. and Alam, M.N. (2013), “Corporate governance in Islamic perspective”, International Journal of Islamic and Middle Eastern Finance and Management, Vol. 6 No. 3, pp. 180-199.

Choudhury, M.A. and Hoque, M.Z. (2006), “Corporate governance in Islamic perspective", Corporate Governance, Vol. 6 No. 2, pp. 116-128.

Covaleski, M.A. and Dirsmith, M.W. (1988), "An institutional perspective on the rise, fall and social transformation of a university budget category", Administrative Science Quarterly, Vol. 33 No. 4, pp. 562-587.

Dacin, M.T., Goodstein, J. and Richard Scott, W. (2002), "Institutional theory and institutional change: introduction to the special research forum", Academy of Management Journal, Vol. 45 No. 1, pp. 45-56.

Deephouse, D.L. (1996), "Does isomorphism legitimate?", Academy of Management Journal, Vol. 39 No. 4, pp. 1024-1039.

Deegan, C. (2002), "The legitimizing effect of social and environmental disclosures - a theoretical foundation", Accounting, Auditing and Accountability Journal, Vol. 15 No. 3, pp. 282-311.

Delener, N. (1994), "Religious contrasts in consumer decision behavior patterns: their dimensions and marketing implications", European Journal of Marketing, Vol. 28 No. 5, pp. 36-53.

DiMaggio, P. (1998), "The relevance of organizational theory to the study of religion", Sacred Companies, Oxford University Press.

DiMaggio, P. and Powell, W.W. (1983), "The iron cage revisited: collective rationality and institutional isomorphism in organizational fields", American Sociological Review, Vol. 48 No. 2, pp. 147-160.

Donaldson, L. and Davis, J.H. (1991), "Stewardship theory or agency theory: CEO governance and shareholder returns", Australian Journal of Management, Vol. 16 No. 1, pp. 49-64.

Farrington, J. and Farrington, C. (2005), "Rural accessibility, social inclusion and social justice: towards conceptualization", Journal of Transport Geography, Vol. 13 No. 1, pp. 1-12.

Feldman, M. and Rafaeli, A. (2002), "Organizational routines as sources of connections and understandings", Journal of Management Studies, Vol. 39 No. 3, pp. 309-331.

Freeman, R.E. (1984), Strategic Management: A Stakeholder Approach, Pitman, Boston, MA.

Gambling, T. and Karim, R.A.A. (1991), Business and Accounting Ethics in Islam, Mansell Publishing Limited, London.

Grais, W.M. and Pellegrini, M. (2006a), "Corporate governance in institutions offering Islamic financial services: Issues and options”, World Bank Policy Research Working Paper 4052, World Bank.

Grais, W.M. and Pellegrini, M. (2006b), "Corporate governance and Shariah compliance in institutions offering Islamic financial services", World Bank Policy Research Working Paper 4054, World Bank.

Grassa, R. (2013), "Shariah supervisory system in Islamic financial institutions new issues and challenges: a comparative analysis between Southeast Asia models and GCC models", Humanomics, Vol. 29 No. 4, pp. 333-348. 
Grassa, R. (2016), “Corporate governance and credit rating in Islamic banks: does Shariah governance matters?”, Journal of Management and Governance, Vol. 20 No. 4, pp. 875-906, doi: 10.1007/s10997-015-9322-4.

Greenwood, R. and Hinings, C.R. (1996), "Understanding radical organizational change: bringing together the old and the new institutionalism”, Academy of Management Review, Vol. 21 No. 4, pp. 1022-1054.

Greuning, H.V. and Iqbal, Z. (2008), “Risk Analysis for Islamic Banks, ”, The World Bank, Publisher Washington, DC.

Hamid, S., Craig, R. and Clarke, F. (1993), "Religion: a confounding cultural element in the international harmonization of accounting?”, Abacus, Vol. 29 No. 2, pp. 131-148.

Handelman, J.M. and Arnold, S.J. (1999), "The role of marketing actions with a social dimension: appeals to the institutional environment”, Journal of Marketing, Vol. 63 No. 3, pp. 33-48.

Haque, A., Osman, J. and Ismail, A.Z.H. (2009), "Factor influences selection of Islamic banking: a study on Malaysian preferences", American Journal of Applied Sciences, Vol. 6 No. 5, pp. 922-928.

Hassan, A.F.S. (2012), "An empirical investigation into the role, independence and effectiveness of Shariah boards in the Malaysian Islamic banking industry”, PhD Thesis, University of Cardiff.

He, Y., Tian, Z. and Chen, Y. (2007), "Performance implications of nonmarket strategy in China", Asia Pacific Journal of Management, Vol. 24 No. 2, pp. 151-169.

IFSB (2009), "Guiding Principles on Shari'ah Governance System for Institutions offering Islamic Financial Services”, Islamic Financial Services Board.

Iqbal, Z. and Mirakhor, A. (2004), "Stakeholders model of governance in Islamic economic system", Islamic Economic Studies, Vol. 11 No. 2, pp. 43-63.

Jensen, M.C. and Meckling, W.H. (1976), "Theory of the firm: managerial behaviour, agency costs, and ownership structure”, Journal of Financial Economics, Vol. 3 No. 4, pp. 305-350.

Kalbers, L.P. and Fogarty, T.J. (1998), "Organizational and economic explanations of audit committee oversight”, Journal of Managerial Issues, Vol. 10 No. 2, pp. 129-150.

Kamla, R. (2009), "Critical insights into contemporary Islamic accounting”, Critical Perspectives on Accounting, Vol. 20 No. 8, pp. 921-932.

Kamla, R. and Alsoufi, R. (2015), "Critical Muslim intellectuals' discourse and the issue of 'interest' (riba): implications for Islamic accounting and banking”, Accounting Forum, Vol. 39 No. 2, pp. 140-154, available at: http://dx.doi.org/10.1016/j.accfor.2015.02.002

Kamla, R., Gallhofer, S. and Haslam, J. (2006), "Islam, nature and accounting: Islamic principles and the nation of accounting for the environment", Accounting Forum, Vol. 30 No. 3, pp. 245-265.

Karbhari, Y., Muye, I., Hassan, A.F.S. and Elnahass, M. (2018), "Governance mechanisms and efficiency: evidence from an alternative insurance (Takaful) market”, Journal of International Financial Markets, Institutions and Money, Vol. 56, pp. 71-92.

Karim, R.A.A. (1995), "The nature and rational of a conceptual framework for financial reporting by Islamic banks", Accounting and Business Research, Vol. 25 No. 100, pp. 285-300.

Karim, R.A.A. (2001), "International accounting harmonization, banking regulation, and Islamic banks”, The International Journal of Accounting, Vol. 36 No. 2, pp. 169-193.

Khadaroo, I. and Shaikh, J.M. (2007), "Corporate governance reforms in Malaysia: insights from institutional theory', world review of entrepreneurship”, Management and Sustainable Development, Vol. 3 No. 1, pp. 37-49.

Khan, M.M. and Bhatti, M.I. (2008), "Islamic banking and finance: on its way to globalization", Managerial Finance, Vol. 34 No. 10, pp. 708-725.

Maali, B., Casson, P. and Napier, C. (2006), "Social reporting by islamic banks", Abacus, Vol. 42 No. 2 , pp. 266-289.

Majeed, S., Aziz, T. and Saleem, S. (2015), "The effect of corporate governance elements on corporate social responsibility (CSR) disclosure: an empirical evidence from listed companies at KSE Pakistan”, International Journal of Financial Studies, Vol. 3 No. 4, pp. 530-556.

\section{Application of institutional theory}


PRR

5,1

Mallin, C., Farag, H. and Ow-Yong, K. (2014), "Corporate social responsibility and financial performance in Islamic banks", Journal of Economic Behavior and Organization, Vol. 103, pp. S21-S38.

Mettawa, S.A. and AlMossawi, M. (1998), "Banking behaviour of Islamic bank customers perspectives and implications", International Journal of Bank Marketing, Vol. 16 No. 7, pp. 299-313.

Meyer, J.W. and Rowan, B. (1977), "Institutionalized organizations: formal structure as myth and ceremony", American Journal of Sociology, Vol. 83 No. 2, pp. 340-363.

Meyer, J. and Rowan, B. (1991), "Institutionalized organizations: formal structure as myth and ceremony", in Powell, W. and DiMaggio, P. (Eds) The New Institutionalism in Organizational Analysis, University of Chicago Press, Chicago, pp. 41-62.

Mittal, R.K., Sinha, N. and Singh, A. (2008), "An analysis of linkage between economic value added and corporate social responsibility”, Management Decision, Vol. 46 No. 9, pp. 1437-1443.

Morphew, C.C. (2009), "Conceptualizing change in the institutional diversity of US colleges and universities", The Journal of Higher Education, Vol. 80 No. 3, pp. 243-269.

Morphew, C.C. and Huisman, J. (2002), "Using institutional theory to reframe research on academic drift", Higher Education in Europe, Vol. 27 No. 4, pp. 491-506.

Morrison, S. (2014), "Shariah boards and the corporate governance of Islamic banks in the United Kingdom”, Journal of Islamic Economics Banking and Finance, Vol. 10 No. 1, pp. 96-109.

Nathan, S. and Ribieri, V. (2007), "From knowledge to wisdom: the case of corporate governance in Islamic banking”, VINE, Vol. 37 No. 4, pp. 471-483.

Obid, S.N.S. and Naysary, B. (2014), "Toward a comprehensive theoretical framework for Shariah governance in Islamic financial institutions", Journal of Financial Services Marketing, Vol. 19 No. 4, pp. 304-318.

Oliver, C. (1988), "The collective strategy framework: an application to competing predictions of isomorphism", Administrative Science Quarterly, Vol. 33 No. 4, pp. 543-561.

Oliver, C. (1991), "Strategic responses to institutional processes", Academy of Management Review, Vol. 16 No. 1, pp. 145-179.

Oliver, C. (1997), "Sustainable competitive advantage: combining institutional and resource based views", Strategic Management Journal, Vol. 18 No. 9, pp. 697-713.

Parasuraman, A., Zeithaml, W. and Berry, L. (1985), "A conceptual model of service quality and its implications for future research", Journal of Marketing, Vol. 49 No. 4, pp. 41-50.

Parsons, T. (1956), "Suggestions for a sociological approach to the theory of organizations", Administrative Science Quarterly, Vol. 1 No. 1, pp. 63-85.

Parsons, T. (1960), Structure and Process in Modem Societies, Free Press, Glencoe, IL.

Pfeffer, J. (1981), "Management as symbolic action: the creation and maintenance of organizational paradigms", in Cummings, L. and Staw, B. (Eds) Research in Organizational Behavior, Vol. 13, JAI Press. Greenwich, CT, pp. 1-52.

Pfeffer, J. and Salancik, G.R. (1978), The External Control of Organizations: A Resource Dependence Approach, Harper and Row Publishers, New York, NY.

Platonova, E., Asutay, M., Dixon, R. and Mohammad, S. (2016), "The impact of corporate social responsibility disclosure on financial performance: evidence from the GCC Islamic banking sector", Journal of Business Ethics, available at: https://doi.org/10.1007/s1055_1-016-3229-0

Rammal, H.G. (2006), "The importance of Shariah supervision in Islamic financial institutions", Corporate Ownership and Control, Vol. 3 No. 3, pp. 204-208.

Rashid, M., Hassan, M.K. and Ahmad, A.U.F. (2014), "Quality perception of the customers towards domestic Islamic banks in Bangladesh", Journal of Islamic Economics, Banking and Finance, Vol. 5 No. 1, pp. 109-131.

Roberts, B. and Greenwood, R. (1997), "Integrating transaction cost and institutional theories: toward a constrained-efficiency framework for understanding organizational design adoption”, Academy of Management Review, Vol. 22 No. 2, pp. 346-373. 
Schur, L., Kruse, D. and Blanck, P. (2005), "Corporate culture and the employment of persons with disabilities", Behavioral Sciences and the Law, Vol. 23 No. 1, pp. 3-20.

Scott, W.R. (1987), "The adolescence of institutional theory", Administrative Science Quarterly, Vol. 32 No. 4, pp. 493-511.

Scott, W.R. (2004), "Reflections on half a century of organizational psychology", Annual Review of Sociology, Vol. 3, pp. 1-21.

Scott, W.R. (2008), Institutions and Organizations: Ideas and Interests, Sage Publications, Thousand Oaks, CA.

Suchman, M.C. (1995), "Managing legitimacy: strategic and institutional approaches", Academy of Management Review, Vol. 20 No. 3, pp. 571-610.

Tinker, T. (2004), "The enlightenment and its discontents: antinomies of christianity, islam and the calculative science", Accounting, Auditing and Accountability Journal, Vol. 17 No. 3, pp. 442-475.

Tolbert, P.S. and Zucker, L.G. (1983), "Institutional sources of change in the formal structure of organizations: the diffusion of civil service reform, 1880-1935”, Administrative Science Quarterly, Vol. 28 No. 1, pp. 22-39.

Tsai, M.C., Lai, K.H. and Hsu, W.C. (2013), "A study of the institutional forces influencing the adoption intention of RFID by suppliers", Information and Management, Vol. 50 No. 1, pp. 59-65.

Ullah, S., Harwood, I.A. and Jamali, D. (2016), "Fatwa repositioning: the hidden struggle for Shari'a compliance within Islamic financial institutions", Journal of Business Ethics, available at: https:// doi.org/10.1007/s1055_1-016-3090-1

Weber, M. (1978), Economy and Society: An Outline of Interpretive Sociology, University of CA Press, CA.

Williams, G. and Zinkin, J. (2010), "Islam and CSR: a study of the compatibility between the tenets of Islam and the UN global compact”, Journal of Business Ethics, Vol. 91 No. 4, pp. 519-533.

Willoughby, W. (1896), An Examination of the Nature of the State, Macmillan, New York, NY.

Wilson, W. (1889), The State and Federal Governments of the United States, D.C. Heath, Boston.

Yeo, R.K. and Youssef, M.A. (2010), "Communicating corporate image into existence: the case of the Saudi banking industry”, Corporate Communications: An International Journal, Vol. 15 No. 3, pp. 263-280.

Yoshikawa, T., Tsui-Auch, L.S. and McGuire, J. (2007), "Corporate governance reform as institutional innovation: the case of Japan”, Organization Science, Vol. 18 No. 6, pp. 973-988.

Zahra, S.A. and Pearce, J.A. (1989), "Boards of directors and corporate financial performance: a review and integrative model", Journal of Management, Vol. 15 No. 2, pp. 291-334.

Zucker, L.G. (1977), "The role of institutionalization in cultural persistence", American Sociological Review, Vol. 42 No. 5, pp. 726-743.

Zucker, L.G. (1987), "Institutional theories of organization”, Annual Review of Sociology, Vol. 13 No. 1, pp. 443-464.

\section{Further reading}

Okumus, H.S. and Genc, E.G. (2013), "Interest free banking in Turkey: a study of customer satisfaction and bank selection", European Scientific Journal, Vol. 9 No. 16, pp. 144-166.

\section{Corresponding author}

Md. Kausar Alam can be contacted at: kausarflorence@gmail.com

For instructions on how to order reprints of this article, please visit our website:

www.emeraldgrouppublishing.com/licensing/reprints.htm

Or contact us for further details: permissions@emeraldinsight.com

Application of institutional theory 